\title{
Palabras en guerra. La experiencia revolucionaria y el lenguaje de la reacción
}

\author{
Words at War. The Revolutionary Experience and Reactionary \\ Language
}

\author{
Encarna García Monerris \\ Carmen García Monerris \\ Universitat de València \\ «Era ralea que se infiltraba en todas partes, combatiendo \\ la fe cristiana y la autoridad de los gobiernos legítimos, \\ en nombre de una < filantropía $>$, de una aspiración a la \\ felicidad y a la democracia, que sólo ocultaban una conjura \\ internacional para destruir el orden establecido». \\ (Alejo Carpentier, El Siglo de las Luces)
}

Recibido: 2-III-2011

Aceptado: 14-IX-2011

\section{Resumen}

Este trabajo se plantea como objetivo una aproximación nueva al pensamiento reaccionario surgido a raíz de la experiencia revolucionaria española a partir de la obra de Rafael de Vélez, Preservativo contra la irreligión. En él abordamos el estudio de la reacción como parte inherente al propio proceso revolucionario. El espejo deformado de esa revolución, que daba paso a un nuevo escenario de la política y de lo público, eran las propuestas de una tradición inventada por los reaccionarios que, en muchos aspectos, resultaba tan novedosa como los principios revolucionarios que combatía. La dialéctica Ilustración-Antiilustración se subsumía, a partir de 1808, en la dialéctica Revolución-Contrarrevolución.

\footnotetext{
* Este trabajo forma parte del proyecto de investigación FFI2008-02107, de la Secretaría de Estado de Universidades del Ministerio de Ciencia e Innovación.
} 
Palabras clave: Revolución, Reacción, Ilustración, Antiilustración, Filosofía, Patriota, Afrancesado.

\begin{abstract}
This paper aims to introduce a new approach to the study of the reactionary thought emerged from the experience of the Spanish (liberal) revolution. It focuses on Rafael de Velez's work Preservativo contra la irreligión and it approaches the study of reaction as an inherent part of the revolutionary process itself. The distorted mirror of that revolution, which gave way to a new policy arena and a new conception of the public, gave birth to an invented tradition which in many respects, was as novel as the revolutionary principles that reactionaries were fighting. The dialectic Enlightenment and anti-Enlightenment was subsumed, from 1808 on, in the dialectic Revolution- Counter-Revolution.
\end{abstract}

Keywords: Revolution, Reaction, Enlightenment, Anti/Counter-Enlightenment, Philosophy, Patriot, Afrancesado. 
Estamos tan acostumbrados a establecer de manera directa un nexo entre Ilustración y Revolución, y a pensar ese momento histórico desde la perspectiva del triunfo ineluctable de la Razón y del Progreso, que olvidamos con frecuencia que la Ilustración tuvo su Antiilustración y que la Revolución, desde el momento mismo de su estallido, tuvo su Reacción ${ }^{1}$. Ambas se mostraron como las dos caras de una misma moneda, con una fecha y un acta de nacimiento idénticas. Difícilmente podemos captar el alcance del proceso abierto en 1789 sin el posicionamiento de sus contrarios y, a su vez, el carácter de estos no puede ser entendido sin el brutal trauma que supuso la ruptura revolucionaria.

Conforme el concepto de «revolución» se iba cargando de nuevas connotaciones en los albores de la contemporaneidad, el inicial y mecánico sentido de la «reacción» iba a su vez definiendo y marcando también los límites y expectativas de un proyecto que nacía precisamente por oposición a aquella y que venía atravesado de las mismas señas de identidad universalistas y voluntaristas ${ }^{2}$. Una universalidad que contribuía a delimitar el conflicto abierto como un enfrentamiento de carácter eminentemente ideológico, en el que la Religión se batía contra la Filosofía; y un voluntarismo que, de manera muy importante, concernía y ponía en valor las nuevas determinaciones morales y la capacidad de acción de los sujetos ${ }^{3}$. Revolucionarios y reaccionarios comul-

1. Sobre las corrientes antiilustradas y sus orígenes, BERLIN, Isaiah, Contra la corriente, México, F.C.E., 1992, especialmente su ensayo «La contrailustración», pp. 59-84; del mismo autor, El fuste torcido de la humanidad, Barcelona, Península, 1992. Ver también el libro de SORIANO, Ramón, La Ilustración y sus enemigos, Madrid, Tecnos, 1988 y el de Paguen, Anthony con el mismo título, Barcelona, Península, 2002. A propósito de ese sentido común apuntado, no debe sorprendernos que en pleno franquismo, los tradicionalistas no aceptaran el dictamen de J. Ortega y Gasset, cuando en uno de sus textos (El ocaso de las revoluciones, 1927), afirmaba que la reacción no era «más que un parásito de la revolución». La conciencia de su modernidad y pertinencia histórica parecía bastante rotunda.

2. KOSELLECK, Reinhart, «Semántica del concetto di rivoluzione», en VV.AA., La rivoluzione francese e l'ídea di rivoluzione, Milán, Franco Angeli, 1986, pp. 7-17; HOBSBAWM, Eric J., «La revolución», en PORTER, Roy y TEICH, Mikulás (eds.), La revolución en la Historia, Barcelona, Crítica, 1990, pp. 16-70; STAROVInSky, Jean, «Acción y Reacción», en FERRONE, Vincenzo y ROCHE, Daniel (eds.), Diccionario histórico de la Ilustración, Madrid, Alianza Editorial, 1999, pp. 99-111.

3. En este aspecto concreto de la determinación moral de los individuos, la influencia de Inmanuel Kant será decisiva. Véase, por ejemplo, a manera de introducción al tema, Villacañas, José Luis, Kant y la época de las revoluciones, Madrid, Akal, 1977; o del mismo autor, La quiebra de la razón ilustrada: idealismo y romanticismo, Madrid, Cincel, 1988. De manera particular, la obra de KANT, Inmanuel, «Respuesta a la pregunta: ¿qué es la Ilustración», en ¿Qué es la Ilustración?, Madrid, Tecnos, 1989, pp. 17-29) (edic. e introducción de Agapito Maestre). 
garon, en esta línea, del mismo sentido de la acción en un idéntico escenario que los unía y enfrentaba, y que no era otro que el de lo político, el de lo público y el de la opinión pública.

Sabido es que para Antoine Compagnon los verdaderos modernos fueron los antimodernos, aquellos que vivieron la modernidad entre el desarraigo, la tensión, el rechazo, la resistencia y la ambivalencia. El primer «moderno», en este sentido, sería Joseph de Maistre. En él y en los que participaron de su discurso y posición se encuentran las «figuras de la antimodernidad», aquellos «lugares comunes» que diseñaron un mundo antitético al de la propia revolución: la contrarrevolución, como figura histórica o política; la antiilustración, como figura filosófica; el pesimismo, como figura moral o existencial; el pecado original, como figura teológica; lo sublime, como figura estética y la vituperación o imprecación como figura de estilo4.

¿Hasta qué punto estos topoi estuvieron presentes en el discurso y en el pensamiento antiilustrado y reaccionario español? Como nos recordara hace ya bastantes años Javier Herrero, en un excelente y casi pionero trabajo sobre los orígenes del mismo, éste no fue «más que una manifestación del gran movimiento europeo en su reacción, primero contra la Enciclopedia y, más tarde, contra la Revolución Francesa». Añadía que la tan exaltada tradición española, «ni era tradición, ni era española». El interés intelectual por rastrear los orígenes del romanticismo español de los años 30 y 40 del siglo XIX le llevó, casi sin pretenderlo, a bucear en una España y en unos años en los que descubrió «todo un mundo estridente, violento (...), un mundo precursor de las violencias totalitarias de nuestro siglo. Demagogos airados denunciaban oscuras conspiraciones; paranoicos fanáticos acusaban a presuntos afrancesados de atentar contra las sagradas instituciones del Trono y del Altar». Por mucho que la interpretación de Javier Herrero obedezca a imperativos historiográficos y políticos del momento, a partir de los cuales caben bastantes matizaciones hoy en día, lo cierto es que tuvo, entre otras cosas, la virtualidad de plantear implícitamente la indisoluble relación entre Revolución y Reacción, y su más que evidente carácter ultranacional ${ }^{5}$.

4. Compagnon, Antoine, Los antimodernos, Barcelona, Acantilado, 2007, p. 33 y ss.

5. Herrero, Javier, Los orígenes del pensamiento reaccionario español, Madrid, Alianza Universidad, 1988, «Introducción», pp. 13-24. Su interpretación, desde luego, debe contextualizarse en el momento de su formulación, en lucha fundamentalmente contra las ideas menendezpelayistas, empeñadas en buscar los orígenes patrios y la esencia de lo español. Desde este punto de vista, es verdad que las conclusiones de Herrero insistían, tal vez demasiado, en los orígenes europeos de este movimiento que, con todo, es verdad que, exactamente igual que la Revolución, debe entenderse en un contexto más amplio que el estrictamente «nacional». Una revisión del planteamiento de Herrero, que 
En efecto; en medio del proceso revolucionario español y en plena lucha contra el ejército francés, puestos a definir o concretar quiénes eran los «patriotas» y quiénes los auténticos «afrancesados», resultó evidente que el pensamiento reaccionario acabó estableciendo nuevas líneas divisorias. Al reaccionario, en el fondo, no le interesaban España ni los «patriotas», sino la Revolución. «Afrancesados» resultaron serlo todos: josefinos, napoleónicos o «patriotas» antifranceses que comulgaban con los presupuestos del reformismo y de la racionalidad. Resultaba evidente que la Revolución instauraba un mundo nuevo proyectado hacia el futuro y que las fronteras de su acción no eran nacionales. El espejo deformado de esa Revolución eran las propuestas de una tradición inventada por los reaccionarios que en muchos aspectos resultarían tan novedosas como los propios principios revolucionarios que combatían. Los dos «inventaban» y los dos eran, a su manera, «revolucionarios». Tal vez por eso, Eugenio di Rienzo, a propósito de la dialéctica revoluciónreacción, propuso en su momento el paradigma de las «dos revoluciones» ${ }^{6}$.

Se caería en el riesgo de ser conceptualmente imprecisos si aseveráramos que la tradición residía en exclusividad en los reaccionarios y que ellos eran los tradicionales por excelencia. Este aspecto, por el contrario, habría que buscarlo, de manera más originaria, en personajes y posturas políticas como la que representaba Edmund Burke, extraordinariamente respetuoso, él sí, con la historia, por mucho que ayudara también a difundir el topoi de la «conspiración» ${ }^{7}$. Paradójicamente, el abad Barruel, auténtico y primigenio responsable de este lugar común, que por esas mismas fechas publicaba sus Memorias para servir a la Historia del jacobinismo (1797-1798), creaba un mundo nuevo opuesto a la tradición. El presente, como catarsis, era el punto de partida. Sería en este autor en quien, especialmente, se mirarían los reaccionarios españoles a la hora de alimentar el componente antiilustrado y hostil a la Revolución que encontramos en sus escritos. Para muchos de

interpreta el pensamiento reaccionario español desde coordenadas historiográficas renovadas, en LÓPEZ Alós, Javier, Entre el trono y el escaño. El pensamiento reaccionario espanol frente a la Revolución liberal (1808-1823), Madrid, Congreso de los Diputados, 2011.

6. RIENZO, E. di (a cura di), Nazione e controrivoluzione nell'Europa contemporanea, 17991848, Milano, Guerini e Associati, 2004. Al respecto, ver también el cap. II del libro de MAYER, Arno J., Les Furies, 1789-1917. Violence, vengeance, terreur aux temps de la révolution française et de la révolution russe, Paris, Fayar, 2002, pp. 48-68, donde analiza la contrarrevolución como «antítesis indispensable de la revolución».

7. BURKE, Edmund, Reflexiones sobre la Revolución en Francia (1790), Madrid, Alianza, 2003. Un análisis extraordinariamente sugerente de esta obra, perfectamente contextualizada en el momento histórico e ideológico en el que se produjo, en DíEz ÁlvarEZ, Luis Gonzalo, Edmund Burke y la moderna guerra ideológica, Madrid, Universidad Francisco de Vitoria, 2010. 
ellos, 1789 y la guerra contra Napoleón constituyeron momentos y lugares de los que no podían prescindir en la elaboración de su discurso, siempre por negación. También en ellos, desde este punto de vista, el presente era un mito y no solo una prometedora proyección utópica hacia el futuro ${ }^{8}$. El presente era, evidentemente, la revolución, aunque los precedentes venían gestándose desde hacia un tiempo. Esos precedentes, igual para los reaccionarios que para los revolucionarios, remitían a la crisis de la monarquía hispánica, y a la naturaleza y características de la Ilustración y del reformismo español.

No podemos olvidar que la expulsión de los jesuitas de España, lejos de constituir un acto aislado y particular de la política hispana, se inscribía en una actuación de carácter más amplio, europea, que atacaba de manera directa los intereses de la Iglesia9. El embate regalista que este hecho supuso escondía en el fondo una lucha entre universalidades: la de una monarquía en pleno despliegue a costa de poderes intermedios o superiores a ella; y la más esencial de la Iglesia, definitoria de la propia estructura eclesial. Esto alimentó la percepción de una especie de conjura universal, que culminaría con la eliminación de todo tipo de religión en la Revolución francesa. El problema, sin embargo, no era sólo entre jurisdicciones, sino que afectaba de manera directa a aspectos materiales. No en vano, la religión, desde la perspectiva ilustrada, legitimaba el antiguo orden social y político. Como exclamara en un momento Diderot, haciéndose eco de la posición axial del binomio política-religión en el Antiguo Régimen, «imponedme el silencio sobre la religión y el gobierno, y no tendré nada más de que hablar». Imaginar otro gobierno, pensar otra legitimidad, o proyectar otra ingeniería social presuponía, inevitablemente, ya no tanto atacar la religión cuanto colocarla en otro lugar en la cultura y en la historia de la humanidad ${ }^{10}$.

Los apuros y necesidades hacendísticas de la monarquía, las medidas tomadas por sus ministros y las respuestas sociales a las mismas diseñaron, a su vez, un trasfondo conflictivo sobre el que incidirían los efectos de la

8. A propósito de las diversas percepciones del tiempo histórico y político, ver el citado estudio Villacañas, José Luis, Kant y la época de las revoluciones..., pp. 23-68.

9. Se ha ocupado ampliamente de este tema GIMÉNEZ LóPEZ, Enrique, entre otros, en trabajos como «Los jesuitas y la Ilustración», Debats, n. ${ }^{\circ} 105$ (2009), pp. 131-140; Portugal y España contra Roma. Los inicios del proceso de extinción de la Compañía de Jesús (1767-1769)», en GIMÉNEZ LÓPEZ, Enrique (coord.), Y en el tercero perecerán: gloria caída y exilio de los jesuitas españoles en el siglo XVIII: estudios en homenaje a P. Miquel Batllori i Munné, Alicante, Universidad de Alicante, 2002, pp. 293-324.

10. La cita de Diderot en Ginzo FernándeZ, Arsenio, «Diderot preceptor de la Europa Ilustrada», Anales del Seminario de Historia de la Filosofía, n. 20 (2003), pp. 107-143, concretamente en p. 121. 
Revolución Francesa de 1789. El inicio del reinado de Carlos IV y la propia política de reformas llevada a cabo hasta el momento se verían empañados de inmediato por el temor al contagio de las ideas y noticias que llegaban de Francia. Se trataba de un momento de inflexión respecto a la dinámica política anterior. El llamado «cordón sanitario» del ministro Floridablanca no sólo buscaba evitar la entrada de las ideas «subversivas», sino también que no se escribiera sobre ellas dentro de España. Ni a favor ni en contra. Como si de una epidemia de peste se tratara, había que impedir su expansión. Las ideas, pero también los hombres procedentes del país vecino, eran el mal a conjurar. Sabemos, no obstante, que, pese a las precauciones tomadas, esas ideas y los escritos circularon clandestinamente. El momento y el ambiente favorecían, por tanto, lo que se conformó como una auténtica movilización contrarrevolucionaria ante las amenazas de una filosofía de efectos mesiánicos. Tal y como la historiografía ha puesto de relieve, el rearme de la Iglesia fue un hecho incuestionable en medio de esta repulsa a la Revolución: los eclesiásticos jugaron un doble papel, el de guardianes de la ortodoxia de la sociedad y el de propaganditas de la contrarrevolución. A través de obras y escritos de baja calidad literaria, en muchas ocasiones desplegaron todo un activismo que conectaba con la mentalidad antiilustrada anterior a 1789. Sus arengas inflamadas y el uso de la fuerza y de la represión arbitraria por parte de la monarquía, y la inseguridad que la situación creaba por momentos, aconsejaron la pertinencia de prohibir todo tipo de escritos, incluidos aquellos que pretendían hacer una defensa de los derechos de soberanía y de la constitución de la monarquía. Silenciar a los contrarrevolucionarios era una forma de silenciar la Revolución y sus efectos. No de otro modo pueden interpretarse las dificultades y la censura de que fueron objeto las obras de autores como Hervás y Panduro, o como la del francés Barruel. La Real Orden de enero de 1795 obraba en este sentido ${ }^{11}$.

11. Sobre Floridablanca se puede consulta HERNÁNDEZ FRANCO, Juan, La gestión política y el pensamiento reformista del conde de Floridablanca, Murcia, Universidad de Murcia, 2008; y MenÉNDEZ Peláez, Jesús (coord.), José Moñino y Redondo, conde de Floridablanca (1728-1808): estudios en el bicentenario de su muerte, Gijón, Fundación Foro Jovellanos del Principado de Asturias, 2009, especialmente los dos trabajos de Manuel de AbolBrason y el de Santos M. Coronas, que repasa su trayectoria como fiscal del Consejo de Castilla. Sobre la publicística, opinión pública y ofensiva contra la revolución, son especialmente indicados los trabajos de DUFOUR, Gérad, sobre todo «La Inquisición y la Revolución Francesa», en DIEGO, Emilio de y otros (coords.), Repercusiones de la Revolución francesa en España, Madrid, Universidad Complutense de Madrid, 1990, pp. 545-554; o «Godoy y la Iglesia», Pasado y Memoria: Revista de Historia Contemporánea, n. 3 (2004), pp. 125-134. También, el clásico estudio de ElORZA, Antonio, «El temido árbol de la libertad», en AYMES, Jean-René (ed.), España y la Revolución Francesa, 
Que el componente antirreligioso de la Ilustración no se mantenía sólo en el plano de las ideas, y ni siquiera en el de la pugna de jurisdicciones, quedó de manifiesto con la desamortización de Godoy en 1798. Más allá de la significación estrictamente económica de la medida, la peligrosidad de la misma, para amplios sectores de la sociedad del Antiguo Régimen, se puso de manifiesto por la relación indiscutible que se establecía entre religión y propiedad a través de la actuación despótica ministerial. Los efectos benéficos de la venta de bienes eclesiásticos apenas se percibían por parte de quienes vieron en ese acto un auténtico ataque a las propiedades de la Iglesia. Atacar sus bienes era atacar a la religión, a la sensibilidad de los católicos y al cristianismo. Al mismo tiempo eso confirmaba el creciente ambiente de inseguridad jurídica y de deriva despótica de la propia monarquía. Desde esa sensibilidad, un conjunto de autores, con sus escritos y actuaciones públicas, representaron y recogieron toda esa mitología reaccionaria que el setecientos europeo fue generando de la mano de los antiilustrados. Son muchos los autores españoles en quienes se encarna esta corriente. Nos limitaremos en este trabajo a una relectura de uno de ellos, Rafael de Vélez, seguramente el que mejor supo recoger la teoría de la conspiración del abad Barruel, a través de sus varias publicaciones, en un momento decisivo para la Monarquía hispana como fueron los años de las Cortes de Cádiz.

Rafael de Vélez (Manuel José Anguita Téllez, Vélez Málaga, octubre 1777-monasterio de Herbón, agosto 1850) era fraile capuchino desde los 15 años y fue ordenado sacerdote en 1802. Cuando estalló la Guerra de la Independencia se refugió en un convento de Cádiz, ciudad desde la que dirigió la publicación El Sol de Cádiz y donde apareció su primera obra, Preservativo contra la irreligión, de extraordinaria difusión y acogida no sólo en la Península, sino también por los territorios americanos de la Monarquía. En 1816 es nombrado obispo de Ceuta y en 1824 arzobispo de Burgos y luego de Santiago. Tras la muerte de Fernando VII, destacó por su resistencia a las desamortizaciones. Acusado de connivencia con los carlistas, fue desterrado a Menorca en abril de 1835, pasando posteriormente, en junio de 1844, a Galicia. No era ésta la primera vez que sufría la persecución de los liberales.

Barcelona, Crítica, 1989, pp. 69-117. En este mismo volumen, el trabajo de DOMERGUE, Lucienne, «Propaganda y contrapropaganda en España durante la Revolución Francesa (1789-1795)», pp. 118-167. De manera general, CALLAHAN, William, Iglesia, poder y sociedad en España, 1750-1874, Madrid, Nerea, 1989; o MeSTRE, Antonio y LA PARRA, Emilio, «Política y cultura en el reinado de Carlos IV», en MolAs, Pedro y GuimERÁ, Agustín (coords), La España de Carlos IV, Madrid, Asociación de Historia Moderna, 1991, pp. 189-204. 
Ya durante el Trienio, su enfrentamiento con las autoridades políticas y constitucionales de Ceuta le acarrearon el destierro de esa ciudad y un periplo de varios años por distintos conventos de la Península. Su favorable acogida durante los gobiernos absolutistas ha llevado a insinuar que se trataba de uno de los más importantes apoyos doctrinales de la restauración fernandina. Vélez, muy por encima de su condición eclesiástica y de su, seguramente, muy relativa carga doctrinaria, es un producto de la dialéctica revolución-reacción. Su activismo, de netas y contundentes repercusiones políticas, le convierte en un personaje casi romántico, que acabó transitando por toda la geografía de la reacción, para acabar deviniendo en un auténtico mártir de la misma. Su empecinada lucha desde la condición eclesial contra las autoridades políticas en momentos constitucionales recuerda mucho, salvando las distancias, similares comportamientos de otros héroes contrarrevolucionarios como los del militar y capitán general Francisco Javier Elío. Ambos, Vélez y Elío, fueron protagonistas activos de ese otro lado de la Revolución que fue la Reacción. Los dos mártires, y los dos embalsamados y enterrados bajo la cripta de dos catedrales, la de Santiago y la de Valencia, respectivamente ${ }^{12}$.

En el Cádiz cercado y agitado de las Cortes, en un momento, además, de plena efervescencia de la opinión y de los diversos grupos políticos en torno a temas tan cruciales como el de la abolición de los señoríos o la discusión del propio texto constitucional, nuestro capuchino publicó una extensa obra, de valor literario desigual, pero de extraordinaria significación para fijar, desde la perspectiva española, aquellos tópicos reaccionarios que ya se habían elaborado para el caso francés. El Preservativo contra la irreligión o los planes de la falsa filosofía contra la Religión y el Estado se publicó por primera vez en $1812^{13}$. La Constitución política de la monarquía española, una monarquía y una constitución todavía para ambos hemisferios, acababa de ver la luz. La obra de Vélez, de una extraordinaria e inmediata difusión, tenía también unas pretensiones netas de universalidad extensible tanto al público de la península como al de las colonias americanas. De hecho, la obra fue objeto, en apenas

12. Sobre Elío hemos publicado un estudio basándonos fundamentalmente en sus cartas desde la Ciudadela de Valencia: GARCía MonerRis, Encarna y GARCÍA MONERRIS, Carmen, La Nación secuestrada. Francisco Javier Elío. Correspondencia y Manifiesto, Valencia, PUV, 2008.

13. El título completo de la publicación es Preservativo contra la irreligión o los planes de la falsa filosofía contra la Religión y el Estado. Realizados por la Francia para subyugar la Europa, seguidos por Napoleón en la conquista de España, y dados a luz por algunos de nuestros sabios en perjuicio de nuestra patria, Cádiz, Imprenta de la Junta de Provincia, 1812. 
un año, de unas diez ediciones, de las cuales dos fueron en México (1812 y 1813), una en la Habana (1813) y otra en Manila (1813) ${ }^{14}$.

La extensa obra, de 216 páginas, estructura en seis capítulos un argumento lógico y escalonado que va desde una idea general sobre la importancia constitutiva de la religión en el ser social humano, hasta el abatimiento de España, no tanto por la ocupación de las tropas francesas, como por el efecto corrosivo de la irreligión y de la filosofía. Una filosofía y unos filósofos que ya han manifestado sus planes y producido sus perversos efectos durante el siglo XVIII en Francia y que, de la mano de Napoleón y sus ejércitos, se han extendido por toda Europa. España, que en un primer momento sabe aunar el concepto de patria con el de religión, es la única capaz de hacer frente al tirano de Europa, pero al primer momento de triunfo sucede, ya en 1812, la inquietante realidad de una patria corrompida y, por tanto, nuevamente en peligro.

La historia para Vélez es la historia de la lucha de la religión contra la filosofía. Desde los orígenes mismos del cristianismo, éste tuvo que hacer frente a las fuerzas que pretendían su destrucción. Éstas se remontaban a tiempos pretéritos, de la misma manera que el hecho religioso es, por definición, el hecho constitutivo de la sociabilidad humana. La religión saca al hombre de su estado salvaje de naturaleza; no es sólo el vínculo más fuerte de la sociedad, sino su fundamento y el del poder mismo. Los intereses de la patria y de la religión «son una misma cosa con los bienes de su particular propiedad» (p. 8).

Desde esta perspectiva, la lucha entre religión y filosofía se reviste de un carácter universal, que trasciende fronteras físicas y temporales. La amenaza se remontaba a los mismos griegos, ese pueblo que generó esa especial raza de seres llamados filósofos, empeñados en descubrir a través de la razón y del logos una verdad que, para Vélez, estaba ya inscrita en la naturaleza religiosa de la sociedad y del poder. Esos hombres, encarnación del deambular del mal a lo largo de siglos y siglos de historia, son conocidos en Europa «con los nombres de iluminados, materialistas, ateos, incrédulos, libertinos, francmasones, impíos» (p. 8). Frente a una religión que actúa, además, como elemento contenedor y modelador de las pasiones y vicios humanos, se levantó desde el

14. De hecho, en este trabajo manejamos la reimpresión de México de 1813, hecha a solicitud del vicario general de capuchinos de las provincias de España y sus Indias, Fr. Mariano de Bernardos, en la oficina de doña María Fernández de Jáuregui. <http:// books.google.es/books?id=vSMQAAAAIAAJ\&printsec=frontcover\&dq=Preservativo+ contra+la+irreligi\%C3\%B3n+de+Rafael+de+V\%C3\%A9lez\&hl=es\&ei=Yp_wTZqDO43 JsgbK94yIBw\&sa=X\&oi=book_result\&ct=result\&resnum $=1 \& v e d=0 C C s Q 6 A E w A A \#$ $\mathrm{v}=$ onepage $\& \mathrm{q} \& \mathrm{f}=$ false $>$ [última consulta: 9 de junio de 2011]. Durante los momentos de restauración absolutista su obra fue objeto también de nuevas ediciones. 
origen de los tiempos una pretendida ciencia nueva fundamentada, que hacía de la razón y de las pasiones sus instrumentos. La historia de la humanidad se reconstruye a partir de dos estirpes o genealogías distintas enfrentadas que, desde las primeras sectas del cristianismo, pasando por la reforma protestante, desembocan en el siglo XVIII. Tantos siglos de lucha no parecían haber supuesto el triunfo de la ciudad de Dios sobre la de los hombres. El infierno seguía vomitando monstruos y la filosofía seguía armando sabios:

«Un ruido sordo, pero espantoso, terrible, semejante al que precede a las erupciones de los volcanes se percibía distintamente desde principios del siglo XVIII en las ciudades de primer orden, como en las aldeas más reducidas, por los paseos, por las tertulias, por los teatros de toda Francia. La filosofía tenía ya todas sus medidas tomadas: por momentos se acercaba el día de su triunfo: reyes, duques, obispos, sabios, personas de la más alta gerarquía se habían alistado en sus banderas. Los papeles públicos eran como las lavas abrasadas vomitadas por el Etna o el Vesubio que todo lo envolvían en sus corrientes, todo lo arrasaban» (pp. 26-27).

Las referencias apocalípticas, con todo, no hacían alusión sólo ni exclusivamente a un mundo natural, sino a espacios y lugares bien habitados y poblados por nombres y hombres que empujan y aceleran con sus escritos y acciones a las fuerzas del mal. Son los respresentantes más significativos al servicio de los «antiguos planes de la filosofía contra la iglesia y contra el Estado» (p. 27): Bayle, Montesquieu, Pufendorf, Diderot, Helvetius, Federico de Prusia, Voltaire, Rousseau, pero también Mirabeau, Hobbes, Condorcet, Dupont o Necker...

La Revolución en Francia, más allá de provocar una falsa representación nacional reasumida por los filósofos como representantes del pueblo, supuso, por la claudicación del rey ante la Asamblea, el comienzo de la cesión de toda la autoridad a aquella. Para el reaccionario, aquí no hay mediación institucional que valga. Esa autoridad y ese poder «siempre que se dexó entero en las manos solas del pueblo, fue la espada con que él mismo se ha dividido, el germen de revoluciones, estragos, muertes, guerras intestinas» (p. 36). Fue a partir de ese momento cuando la violencia de los planes de los filósofos se dirigió contra la Iglesia y la religión. Las medidas contra el poder eclesiástico y los bienes materiales de la institución coronaban el plan de destrucción. Acabada de este modo toda religión en Francia, «se extinguió la Monarquía» (p. 39). El final de una era la aniquilación de la otra.

Pero el mal es universal, de la misma manera que lo es el bien y, uno tras otro, los diversos estados europeos han ido sucumbiendo. A los mecanismos de difusión propios del XVIII pronto siguió la fuerza de los ejércitos y del representante de toda tiranía, Napoleón Bonaparte. Vélez, en su escrito, 
literalmente emprende un viaje por su peculiar geografía de la Revolución francesa, y por su no menos peculiar geografía de la revolución en Europa. La auténtica realidad europea, de monarcas legítimos y de una Europa cristiana, fue sustituida, por efecto de la difusión del iluminismo, por un conglomerado uniforme, en un escenario nuevo en el que los actores eran «la humanidad filantrópica de los filósofos y de sus cómplices» (p. 44). A lo concreto sucedió lo abstracto; a lo diverso, lo uniforme; a la contención, la pasión, y a lo territorialmente diferenciado, lo universal. Y todo ello gracias a la acción de los embajadores que Francia enviaba para corroer y destruir a las monarquías europeas, con la misma habilidad que los filósofos «en el espionaje y en el arte de embrollar» (p. 48).

En ese nuevo escenario, en que la caballerosidad había dejado paso a una especie de zafiedad plebeya, tuvo lugar la representación dramática de la revolución: «Reventó la mina; se sintió la explosión general en toda la tierra; los palacios, las cortes, los tronos de todos los monarcas se estremecieron y los pueblos todos principiaron a padecer» (pp. 44-45). Fue el Apocalipsis a partir del cual era exigible una catarsis que sólo podía contemplarse desde la perspectiva de la acción. Pero los referentes no eran sólo religiosos: eran también naturales y, desde esa perspectiva, la propia revolución, como manifestación misma de esa catarsis, podía ser un mal inevitable al que concurrían también, en un sentido orientador distinto, las propias fuerzas contrarrevolucionarias, que a manera de un katechón retenido a la largo de la historia, irrumpen en un momento decisivo y excepcional para reorientar su curso desbordado ${ }^{15}$. El campo de acción y de desarrollo de la voluntad humana era el diseñado y acotado por la propia ruptura revolucionaria, por mucho que sus claves interpretativas estuvieran en lenguaje religioso.

Desde esos referentes naturales e imprevisibles al mismo tiempo, la revolución se presenta como un torrente que todo lo arrasa y todo lo inunda; es una borrasca que genera olas gigantescas, o un terremoto espantoso que siembra el caos. Es un río de sangre y fuego que anega y arrasa todo lo que encuentra a su paso. En 1792, los actores, los protagonistas de esta catástrofe universal, no eran ya sólo filósofos, sino los sans-culottes y los jacobinos. La filosofía se había encarnado en protagonistas políticos concretos:

15. Curiosamente, el concepto de Katechón fue reactivado por el jurista alemán C. Schmitt en los años treinta en un contexto excepcional y de excepción que exigía, según sus planteamientos, un intervencionismo decisivo para postergar las fuerzas del mal. Al respecto, TRAVERSO, Enzo, A sangre y fuero. De la guerra civil europea (1914-1945), Valencia, PUV, 2009, p. 198 y, en general, pp. 194-201. 
«Sansculotes, jacobinos, filósofos, divisiones de hombres forajidos, consumados en el arte de intrigar, salen de París y de toda la Francia, fiados en sus comunicaciones y tramas con los iluminados de los otros reinos y se esparcen por toda la tierra, llevando en una mano la tea de la discordia, y en la otra el oro y el veneno con que seducir, dar muerte y conquistar» (pp. 45-46).

La universalidad de la «res pública literaria», como la nueva realidad de la civilización europea del siglo XVIII, era constatada y asimilada de forma alarmante por Vélez y los reaccionarios, aunque reinterpretada bajo su peculiar prisma ideológico. Bajo ellos late la modernidad y su comprensión como exigencia para su destrucción o contención.

Mientras los enviados franceses por Europa hacían su trabajo con exactitud, seduciendo y alarmando, Inglaterra parecía saber protegerse de este cruel embate desde 1792. Allí «aún no se han visto los funestos resultados de varios diplomáticos franceses que en diversas épocas se han dirigido a aquel país». Vélez esta seguro de que el tiempo confirmará esta resistente actitud de Inglaterra: «que el generoso Albión no ha consentido ser enturbiado por las artes pérfidas y viles del filosofismo francés», tal y como apunta en una nota aclaratoria a pie de página (p. 48). Sobre una Europa cuya unidad civilizatoria y política parecía desgarrarse y fraccionarse, asomándose al abismo, iba imponiéndose la percepción de la excepcionalidad de una «isla sin revoluciones» que desde temprana fecha empezara a difundir Edmund Burke como gran mito, no ya de la reacción, sino del pensamiento conservador.

La actitud resistente de Gran Bretaña destaca aun más si se observa lo que pasa alrededor. Otros sí que han sucumbido, como por ejemplo el Imperio alemán y, sobre todo, Roma, el centro del cristianismo. Conscientes de su significado, el objetivo de los filósofos era su destrucción y con ella la abolición de la soberanía temporal del Papa: «mientras haya Roma (...) no puede reinar la filosofía». Ahora Bonaparte es a Roma lo que en otro tiempo Escipión fue a Cartago. Escoltado de un formidable ejército y precedido de multitud de filósofos intrigantes, entra en Roma y acomete su destrucción material, al tiempo que se granjea la adhesión de ilustres ciudadanos, leales afrancesados, que conspirarán «contra su patria y contra su príncipe». El Papa sucumbe merced al clima de discordia creado por los conquistadores y al despliegue hipócrita de artimañas de halago y complacencia. Sólo la hipocresía vil o la amenaza criminal pueden explicar la coronación como emperador del propio Bonaparte. Si el Papa sucumbió fue porque, desde su sencillez y candor, virtudes que lo envolvían, no podía llegar a pensar y creer que estaba siendo víctima de un engaño; si se desplazó a París, firmó concordatos, etc., fue porque pensaba que todo era por el «bien de la Iglesia» (pp. 51-52). Vélez apela a Cevallos 
para recordarnos que ya aquél ha dado cuenta de «este proyecto criminal». En este punto reivindica de manera clara el viejo derecho de resistencia contra la tiranía y la guerra injusta:

«Una invasión no es una guerra: de una guerra injusta jamás puede nacer el derecho de conquista. El pueblo que obedece a la fuerza del más poderoso puede, (cesando la violencia) protestarla y sacudir el yugo sin ser rebelde. El príncipe no pierde sus títulos por una injusticia que reclama a la faz de todo el mundo, y a la que no trata de oponerse en razón de su debilidad» (p. 50 $)^{16}$.

Serbia, Holanda, Noruega, Suecia... cierran, finalmente, el recorrido de Vélez por esa geografía víctima de la «filosofía, contra la religión y contra el estado». Su lamento semeja un grito al cielo en demanda de ayuda providencial:

«iNaciones todas de la tierra, monarcas todos del mundo, autoridades de los pueblos, habitantes del globo, ved aquí los famosos generales de la Francia: los grandes políticos, los ilustrados filósofos que han arruinado todos los tronos de la Europa (...), que han obligado a la religión de Jesucristo a desalojarse de do quier que la ha hallado, perseguido sus ministros y despreciándolos como ilusos, fanáticos y supersticiosos» (p. 54).

Cualquier tipo de arma ha sido útil a Francia para ganar sus batallas: los gritos de libertad, igualdad e irreligión; las tramas, la intriga, el soborno, el espionaje, los libelos; venenos y puñales. Todo valía con tal de hacer triunfar los principios de los «filósofos revolucionarios», de Voltaire, de Rousseau y de otros. Y entre todos esos medios e instrumentos hay uno que se apunta no sin maldad: las mujeres. Ellas están entre las armas de que se ha servido Francia para llevar a cabo sus fines y ocupan un honroso lugar al lado de «sansculotes, jacobinos y filósofos». Pero no unas mujeres cualesquiera, sino las mujeres ilustradas. Éstas principiaron sus acciones en la Francia del setecientos y hasta el momento no han cejado en su empeño:

«Mugeres que a expensas de sus favores y de su honor se ganaron la amistad y confianza de su gobierno, iniciadas en los altos misterios de la diplomacia filosófica francesa, forman las partidas de guerrilla de aquellas columnas destructoras; se introducen hasta las trincheras de los reyes, en los gabinetes, en los palacios, con los ministros, con los cortesanos, y con sus halagos y sus amores preparan los grandes triunfos que obtuvo la Francia en los principios de su revolución y que aun no han dexado de conseguir, porque tales emisarias no han dexado de intrigar» (p. 46).

16. Sobre el concepto de tiranía en el contexto de la Guerra de la Independencia, LóPEZ Alós, Javier, «Guerra de la Independencia e instituciones legítimas: la cuestión de la tiranía», Historia Constitucional, n. ${ }^{\circ} 11$ (2010), <http://www.historiaconstitucional. com>, pp. 77-88. 
De este modo tan directo inicia Rafael de Vélez lo que no tardará en revelarse en su escrito, de acuerdo con la rancia tradición cristiana, como una feminización del mal. En efecto, su postura va más allá de las referencias a esas damas ilustradas que, valiéndose de métodos poco honrosos y embaucadores, y habiendo perdido ya el honor, se dejaban ver por los clubes parisinos erigiéndose en abanderadas de esas nuevas formas de sociabilidad y de creación de opinión. La influencia que llega de Francia todo lo invade y España no iba a quedarse atrás. Como una auténtica epidemia, «el corazón sencillo del español» sucumbió, como sucumbieron también las mujeres ante la moda de París y los gustos franceses. Pero en éstas, los efectos no podían dejar de convertirse en vicio, en un recorrido que las lleva desde su condición de señoras a prostitutas:

«Hasta nuestras señoras se llegaron a corromper con la inundación de los franceses, que sobrevino a la paz. Hacían venir dos veces al mes desde París, (por agradar a los franceses) quantas modas inventaban en aquella capital la disolución, el libertinaje, la obscenidad, la prostitución de unas damas, que se elevaron por la revolución a clase de primer orden, perteneciendo por derecho de propiedad a la casa de corrección. Peynados, talles altos, calzados, desenvoltura, desnudez, la molicie, la delicadeza, los vicios hijos legítimos de la inmoralidad que caracterizaba el meretricio de las francesas, y que reprueba nuestra religión y toda moral, en parte o en el todo se llegaron a imitar por muchas españolas» (p. 66).

Toda revolución, sin lugar a dudas, venía precedida de un persistente y soterrado cambio de la moral y de las costumbres.

El retrato que dibuja Vélez es totalmente opuesto a los valores que representa la mujer cristiana. Ésta, y más concretamente lo femenino, se convierte en encarnación del mal y de todos los vicios, en emblema del anticristianismo. Porque el punto de partida, el origen, también es femenino. La filosofía no escasea en recursos, se hace mujer y se viste de mujer: "como una actriz acostumbrada a las tablas, ahora hace las veces de una reyna llena de majestad, y luego de una criada andrajosa» (p. 50). Falsa, camaleónica y seductora, libertina y obscena. Se podía estar hablando de la mujer, pero con igual propiedad de la filosofía o de la razón. De la mano de ambas había nacido un nuevo culto, un nuevo Dios, pero feminizado. De este modo, el desprecio con que Vélez observa este proceso se hace más agudo, más cruel: «Un gran FILÓSOFO, impío y sin religión, ha sustituido a todos los monarcas: y este sólo adora una divinidad fementida...la que él llama la RAZÓN...la FILOSOFÍA» (p. 57). Algo que sólo puede ser masculino ha sido pervertido por lo femenino, se ha feminizado, lo que convierte su condición en algo aún más deleznable. 
El Iluminismo no es para Vélez más que la manifestación del sofismo antiguo. Los ilustrados son los «modernos sofistas» que, al amparo de los medios publicitarios, han conseguido una difusión extraordinaria. El escrito de Vélez, y en general los de todos los reaccionarios, está formulado desde la profunda convicción del arraigo y capacidad extraordinaria de difusión de las ideas liberales. La virulencia de sus escritos y la necesidad misma de ellos como arma de lucha es una constatación de la enorme potencia de los enemigos a abatir, de su capacidad de convicción. El púlpito, pero también los papeles, los panfletos, los libelos, todas aquellas armas que utilizan los enemigos serán también sus armas, y la libertad de pensamiento y de imprenta, que tanto vituperan, sus cauces.

Primero fue Francia la que sucumbió víctima de estas ideas; después cayó toda Europa y ahora, desde 1808, la lucha entre el bien y el mal se libra en España. «En nosotros ha quedado la semilla de la corrupción sembrada por sus escritos... Algunos de los nuestros tratan de cultivarla: ya han manifestado sus ideas a la nación en los papeles públicos: por este medio han descendido sus ideas al pueblo que siempre ha sido sano. Temo que aún quando arrojemos más allá de los Pirineos a nuestros opresores y tiranos, una revolución nueva nos divida» (pp. 13-14). La patria y la religión están en peligro, no tanto por el efecto de la invasión francesa de las provincias, «quanto por la multitud de prosélitos que han ganado a su partido, de que es una prueba indudable tantos periodistas y papeles públicos que se empeñan en ilustrarnos a la francesa, es decir, pervertirnos» (p. 16).

Desde esta consideración, el pensamiento reaccionario produce un desplazamiento y una ampliación del concepto de afrancesado, que adquiere un sentido mucho más inclusivo, abarcando también, desde 1808, a todos los liberales ${ }^{17}$. Esto implica, a su vez, una reacomodación del mismo concepto de patriota. Para Vélez el afrancesamiento es un lento proceso de contaminación de las costumbres iniciado y personificado por la implantación de los Borbones en España y que hunde sus raíces en una secular animadversión de Francia hacia «nuestro honor» $\mathrm{y}$ «nuestras glorias». Lo que Vélez intuye como una especie de «carácter» español, «se mudó» con el influjo de lo francés durante el siglo XVIII. Bien entendido que lo que se rechaza es la denominada Francia

17. Contribuciones recientes al tema en FERNÁNDEZ SARASOLA, Ignacio, «Los afrancesados. Revisión de un concepto», en RAmOS SANTANA, Alberto y ROMERO FERrer, Alberto (coords.), Liberty, liberté, libertad: el mundo hispánico en la era de las revoluciones. 1.Revolución francesa vs. Revolución afrancesada, Cádiz, UCA, 2010, pp. 23-52; y en RAMÓN SOLANS, Francisco Javier, «En torno a la definición de <afrancesado>», Ibid., pp. 85-99. 
heterodoxa, frente a una supuesta ortodoxia representada, entre otros, por Bossuet. Cuando Floridablanca estableció el cordón sanitario, la transfusión de los males se había producido ya. Transfusión de veneno a través de la sangre, porque, efectivamente, desde una perspectiva organicista, el pueblo sano es contaminado por una epidemia, en lo que es ya un contagio generalizado:

«Una especie de frenesí gálico se llegó a apoderar de los cerebros de muchos españoles, que no respiraban más aire que el venido de los Pirineos, inspirado primero por los franceses. Sus miasmas, su corrupción, su veneno, se mezcló en la masa de nuestra sangre, corrió por nuestras venas y arterias, inficionó nuestro corazón, se propagó por la Península; alteró hasta nuestra atmósfera y dio señales evidentes de un contagio general» (p. 65).

El delirio de Vélez rompe los límites de la metáfora moral para convertir la epidemia en un efecto físico concreto contra el que la contrarrevolución debe desplegar sus armas higienistas. Durante todo el siglo XVIII, España estuvo subyugada a Francia, a sus intereses y guerras. Ello le ocasionó el derrumbe financiero, económico y moral. En 1789, todo estaba ya ganado para la causa francesa.

Desde su perspectiva, en España no había ni escritos ni escritores ilustrados. Todo había venido de Francia; ni siquiera la Inquisición había podido frenar o suprimir tan nefasta influencia. Presa de los escritos de los «sabios», España entera entra en un general abatimiento de todos sus «órganos vitales». La universidad, los eclesiásticos, los consejos, «toda la nación» sucumbe paralizada. «En los veinte años últimos -señala- el crimen sirvió de escala para los ascensos, la virtud se desterró públicamente, la religión iba ya a abandonarnos» (p. 71).

En la Guerra contra la Convención, quienes mostraron unidad fueron los soldados, fieles a su religión y a su patria. No así muchos de quienes les dirigían, en quienes ya habían penetrado las ideas nuevas de los modernos sofistas. Estos ya se mostraron partidarios del francés, hasta el extremo de que «nuestros consejos, de quienes debían salir las órdenes y los planes de los exércitos, se procuraron ganar por el partido francés. Las intrigas introduxeron a sus partidarios (que cada día se aumentaban) hasta lo interior del Palacio» (p. 62). Francia, republicana pero unida, dio paradójicamente ejemplo en su lucha contra las potencias que le hacían frente, emulando la lucha de los atenienses contra los persas. La unidad, por el contrario, faltó en España. Había caído Floridablanca y también Aranda. Su sucesor, Manuel Godoy, había iniciado el camino hacia «la ruina». Desde ese momento, la nación consternada se da cuenta de los planes del valido, sabe que ha colocado en el ejército a partidarios de los franceses; sabe que ha alborotado la Corte; sabe, en fin, 
que la firma de la paz con Francia ha sido una humillación: «así sacrifica un favorito para mantenerse en su auge el honor de su patria, de su nación, del mismo rey, que le había elevado a una gloria que jamás mereció» (p. 64).

El valido, un déspota y un sultán en su ministerio, y un sibarita cínico en su palacio, es visto por Vélez como instrumento al servicio de los planes de la nueva filosofía. La política desamortizadora que emprendió constituyó un ataque directo a los bienes materiales de la Iglesia y a sus ministros. Su acción al frente del gobierno no pudo ser más demoledora: favores, rivalidades, insubordinaciones, sobornos. Todo sembró la discordia y la desunión, «una multitud de franceses» se introdujo en las provincias sembrando «las máximas de su revolución y los exemplos de su inmoralidad en todos nuestros pueblos». Los gritos de libertad e igualdad, que pretendían usurpar a los monarcas y las supersticiones de la religión, calaron en un pueblo ignorante e inocente, de sencillo corazón y que fácilmente se deja engañar por esas máximas. De su ya crónica enfermedad, España despierta "postrada ante el trono de su mayor enemiga». Tras la Paz de Basilea y el tratado de San Ildefonso, la patria ya estaba vendida, y nada hicieron para evitarlo ni los Consejos, ni los grandes, «todos callaron».

En determinados momentos, en su peculiar narrativa, Vélez se muestra buen conocedor de vicisitudes y procesos concretos, pero su método no es el de la oposición de lo concreto a un universal, sino oponer a esa universalidad, que es la Ilustración y la filosofía, una universalidad propia, la del reaccionario que juega en el mismo terreno que sus oponentes. Por eso, por mucho que sea consciente de problemas específicos, el mal aparece mucho más allá de la contingencia y adopta la forma de la conspiración:

«No; no llegamos a un estado tan deplorable por el trastorno momentáneo de nuestra monarquía, ni menos por aquellas vicisitudes anexas a todas las naciones de que las historias nos dan repetidos ejemplos. Nuestra ruina fue el resultado infalible de unos planes proyectados por los sabios que en un siglo se habían distinguido en la Francia y que realizaron entre nosotros a fuerza de muchos años» (p. 68).

La revolución en Francia había transformado la monarquía en democracia, la virtud en vicio y la religión en ateismo. Si la virtud falta no se ama a la patria, «la religión se desprecia», «la sociedad de los hombres se hace odiosa». Todo este peligro amenazaba también a España. Sin embargo, ésta reaccionó «porque la religión aún no estaba perdida». Por esta razón, los planes de Francia eran, en primer lugar destruir «nuestra religión», introduciendo «la libertad de pensar sin límites», «el filosofismo» y «la irreligión». Y precisamente para hacer frente a esta amenaza, a los escritos que la contenían y difundían, se 
escribieron obras como la del reverendo Cevallos..., pero fueron insuficientes, a juicio de Vélez.

Los planes de Napoleón no repararon en medios: a través de su emisario contemporizó con Godoy y halagó al Príncipe; envenenó las relaciones en el seno de la familia real. La seducción era su arma. Tras los hechos de El Escorial -apunta Vélez- hizo desterrar a los amigos de Fernando, el duque del Infantado y Escoiquiz, y a quienes creyó que podían oponerse a sus planes (p.80). Retomando la metáfora apocalíptica de la erupción volcánica, Madrid se convierte en «el cráter del volcán que abrasa interiormente a la España». Las provincias alarmadas por los destierros de sus reyes «esperan de un momento a otro una mayor revolución». También Europa desea que España se levante contra el invasor. Paradójicamente, nuestro fraile, que alza su voz en contra de la revolución, acaba invocándola, por mucho que le presuponga una finalidad distinta.

¿Qué es lo que ha conducido a todo esto? ¿Qué es lo que ha dado a Francia un «poder colosal»? En un tono que quiere ser irónico, pero que no puede dejar de traslucir el dolor y el desprecio que le causa y le merece, Rafael de Vélez no duda en la respuesta:

«A los adelantamientos de la filosofía debe la Europa estas nuevas leyes sociales, este moderno derecho de gentes, y estas bases de los estados, que dicta la moderna política (...) Si, la filosofia y la política acordes publican estos principios (...) acomoda todo lo útil: virtud y crimen solo se diferencian por la modulación diversa de las voces: por nada real supone, nada significan: honor, tratados, promesas, garantías, juramento a nadie ligan: son unas ideas quiméricas que la nueva ilustración debe desterrar...» (p. 83).

Todo un mundo de valores está desapareciendo, pero el resentido diagnóstico, también aquí de una manera paradójica, es una manifestación indirecta del reconocimiento de la fuerza de las ideas que empujan al enemigo, de la potencia de la revolución que se combate y de la filosofía que se contrapone al cristianismo. Emerge también la nueva criatura de la política, por mucho que, en contraposición al viejo sentido, se trate de una «falaz política moderna».

A pesar del abatimiento y de la crisis de la hacienda; a pesar de las facciones en que se encontraba dividida la nación; de lo insoportable de las cargas impositivas para el pueblo; del enfrentamiento entre Carlos IV y el príncipe Fernando; a pesar, en suma, de la falta de autoridad («nuestras autoridades eran como unos miembros yermos sin espíritus de vida») y de «la murmuración contra el gobierno, contra el rey y las autoridades»...; a pesar de todo ello, en España se operó una «resurrección política» (p. 101). Puestos a buscar antecedentes, había habido otra resurrección: aquélla que se fue gestando a lo largo de setecientos años de lucha contra el árabe. Si en ese momento la 
contienda se expresó en términos de lucha entre religiones, la nueva y moderna cruzada es la de la religión contra la filosofía. Igual que antes, es la religión la que arma al español y la que pone en manos del pueblo los instrumentos para resistir la agresión francesa. La Guerra de la Independencia es una segunda y crucial cruzada (p. 99) ${ }^{18}$.

España es en estos momentos la Roma que resiste y vence a Cartago; es más que la Esparta que resiste a los bárbaros de Asia. Los ejércitos napoleónicos son superiores a los de Aníbal y a los de Jerjes. La emulación de estas gestas heroicas recorre el mismo camino: desde la desunión y el abatimiento hasta la unidad en torno a la idea de patria. El movimiento español es para Vélez «simultáneo e inesperado» (p. 105); es unitario, está amalgamado por la religión, pero también por la rabia:

«El grande, el pequeño, el rico, el pobre, el eclesiástico, el militar, el que poseía grandes mayorazgos, como el que nada tenía que perder; el joven que estaba ya para unirse al dulce objeto de su amor y el esposo que en el regazo de su consorte disfrutaba de sus ternuras y de los frutos de su unión, hasta el anciano exento por sus años de la lid, todos corren a armarse contra nuestro enemigo común».

En esta bacanal unitaria y en este impulso para la acción que se mueve por un resorte primario e intuitivo, por encima de condiciones materiales, sociales o de creencias, incluso el bello sexo adquiere contornos heroicos y se redime a través de la figura de la matrona, esa mujer que ayuda o da la vida. Por unos momentos superan su timidez y delicadeza innatas, disparan cañones y alientan a sus hijos y esposos exactamente igual que lo hacían las heroínas clásicas (pp. 107-108).

La ciudad asediada que es España, es una nueva Cartago, una moderna Sagunto y una resucitada Numancia. A la revolución de los impíos, España ofrece el ejemplo a Europa de otra heroica revolución. Una revolución de la cual es protagonista inesperado, por encima de cálculos herrados de gabinetes y de políticos, «un pueblo que no sabe calcular» (p. 109), pero que ha hablado ese dos de mayo no tan lejano, y que con su ejemplo ha impulsado a clérigos y frailes a sostener con energía el odio contra Francia. Para ellos reserva

18. Recordemos que también para el pensamiento liberal que se está articulando a través de no menos peculiares lecturas de la historia, la «reconquista» que supone la Guerra de la Independencia tiene también su primer referente lejano en esa peculiar reconquista del suelo patrio ante la ocupación sarracena que anuló la labor de la unitaria España goda. Al respecto, por ejemplo, GARCÍA MONERRIS, Carmen, «El debate preconstitucional: Historia y Política en el primer liberalismo español (algunas consideraciones)», en La ParRa, Emilio y Ramírez, Germán (eds.), El primer liberalismo: España y Europa, una perspectiva comparada, Valencia, Biblioteca Valenciana, 2003, pp. 39-77. 
Vélez explícitamente una parte de la gloria en esta «guerra de religión». Pero los mayores servicios del estado eclesiástico se produjeron en un terreno, el de la opinión pública, que Vélez asume implícitamente desde su percepción de la radical importancia que tiene para el enemigo. El púlpito, las conversaciones privadas, las públicas, los papeles, folletos, hojas volantes...; a través de estas armas, el estado eclesiástico reproduce un papel contrario pero similar, en parte, al de los filósofos. Eso que Vélez llama «nimiedades» tienen toda la fuerza de «minas subterráneas por donde se ha comunicado y propagado el fuego de la insurrección. Por estos mismos conductos se ha avivado, cuando las vicisitudes de la guerra o las malas providencias le apagaron en algunos pueblos o provincias» (p. 113).

La guerra es cruel, pero es una guerra de religión. O mejor, podríamos decir que es cruel porque es de religión. La confusión entre los dos términos es total:

«al lado de las aras de propiciación y de paz, se colocan nuestros fusiles y bayonetas; las banderas que les sirven de señal las reciben de manos de los sacerdotes después de su bendición. De los templos salieron nuestros militares para defender nuestras leyes, nuestros derechos, nuestro rey, nuestra religión» (p. 114).

Precisamente es la simbiosis entre los términos lo que confiere al fenómeno, como respuesta a la revolución, su carácter abarcador y general. El contexto es nuevo, distinto; los contendientes son otros y los valores puestos en juego en el tablero se han redefinido. Pero inevitablemente el escenario recuerda el otro gran momento de ruptura de la unidad europea que representó la Guerra de los Treinta Años (1618-1648). También en ese momento, la guerra fue guerra de religión y también en ese momento fue en el fondo una «guerra civil». También ahora, es ese carácter del enfrentamiento, no sólo entre estados o dinastías, sino entre Filosofía y Religión, el que lo convierte sustancialmente en una guerra civil, «universal» e ideológica. Los principios que se esgrimen contra la Revolución no pueden sino provenir también de otra Revolución. Como sentenciaría Vélez orgullosamente, son los «principios de nuestra revolución $»^{19}$.

A estas alturas, parece innecesario afirmar que nuestro autor, como contrarrevolucionario es, literalmente, un reaccionario, alguien que reacciona

19. Notables sugerencias respecto al concepto, por otra parte más tardío, de «guerra civil europea», aplicado en este caso a la época de 1914-1945, pero con algunos planteamientos de discutible continuidad con la Guerra de los Treinta Años y el momento revolucionario y napoleónico decimonónico, en TrAVERSO, Enzo, A sangre y fuego..., especialmente, pp. 34-44. 
contra la revolución con sus mismas armas y desde idéntico escenario. Sus propuestas y sus escritos no son normativos, no son prescriptivos. Asumen implícitamente una crítica a la deriva despótica de la monarquía española, manifestación de su crisis y del abandono de principios constitutivos básicos, pero sus propuestas adolecen de un mínimo grado de concreción. En sentido estricto, no es una «restauración» del Antiguo Régimen lo que se propugna, aunque sólo sea por las manifestaciones degeneradas que muchos de sus componentes e instituciones exhiben y que, en el fondo, han constituido el caldo de cultivo del que se ha alimentado la revolución. La lógica de su lenguaje y de su discurso, como el de sus oponentes, se mueve en un ámbito más general, más permanente y por ello más esencial. El esquema teocrático de poder, con un vértice en Dios, un Fernando VII como su hombre en la tierra y una comunidad que se resuelve en un pueblo fiel, no agota, ni mucho menos, las propuestas políticas del mundo reaccionario, pero tiene la virtualidad de una generalidad que, por eso mismo, sirve de contrapunto al modelo también universal y general de la lógica revolucionaria y jacobina. Las leyes civiles son «las leyes del evangelio» y los príncipes, como «ministros de Dios, vengadores de sus ofensas y ejecutores de sus iras», son acreedores de respeto y sumisión «aun cuando sean díscolos o malos» (p. 137).

Desde su esquema teocrático, desde el supuesto de la amalgama entre «patria»y «religión», Vélez reduce el significado de «patriota» a la parte del pueblo cristiano, encarnación en esta peculiar cruzada de las «virtudes» que se despliegan contra los «vicios» de unos «afrancesados» que, por la misma redefinición del concepto de "patriota» ha resultado también modificado y ampliado. El binomio «vicio»/«virtud», curiosamente, está reproduciendo en sentido invertido, el escenario radical jacobino en su peculiar lucha contra el complot aristocrático. Si en éstos el terror era el punto neurálgico en el que virtud y crimen se oponían y la fuerza que resolvía el conflicto, en los reaccionarios, el complot de la falsa filosofía encuentra como respuesta la «dictadura del sable»; una guerra también como instrumento de resolución del conflicto entre la moral religiosa y las fuerzas materialistas y ateas.

Vélez es, evidentemente, un antiilustrado; su lucha contra la universalidad de la razón, contra sus emisarios, los filósofos, contra los sabios, es la razón de ser de su escrito. Hay algo de verdad en su percepción del carácter universal, de la capacidad de contagio de los efectos de esta filosofía; una razón que ya en su momento supo captar perfectamente Edmund Burke, y una razón en ese momento perfectamente antijacobina que supo captar también el abad Barruel. Pero si Burke supo responder al carácter abstracto y universal de la revolución francesa con todas las baterías de la cultura empírica inglesa 
y con toda la carga de la historia, tanto Barruel como, desde luego, Vélez, oponen a la abstracción de la revolución francesa otra abstracción mayor. El mundo de estos reaccionarios no es nunca el mundo de la historia, sino el mundo de unos apriorismos teológicos que les permiten la construcción de un esquema evolutivo de la humanidad en el que la providencia sustituye a la razón. En ellos no está la tradición, a pesar de lo que dijera Menéndez Pelayo. El mundo de la tradición es el mundo de la historia, y ésta se recluye preferentemente en lo que será el pensamiento conservador.

La universalidad y la abstracción de Vélez es, desde luego, el terreno apropiado para lo sublime, para un heroísmo que rebasa la belleza de lo contingente. Lo bello es mortal por humano, pero lo sublime es inaprensible. Ese alo estético lo transporta a un lenguaje atravesado de pasión, inductor de un fanatismo sanguinario y cruel que, no obstante, como pasión grande y fuerte que es, enaltece el corazón de los hombres y bien dirigido por la religión puede producir sublimes virtudes. En Vélez es mil veces preferible un pueblo fanático a un pueblo afeminado por la irreligión, el espíritu reflexivo y filosófico (pp. 128-129). Ha sido el avance de estos males el que, precisamente, ha roto los lazos morales y políticos de un ser humano que, por el hecho de serlo, es desde el primer momento religioso y político. La revolución es esa explosión que propicia la emergencia, en su peculiar escenario, de hombres y mujeres (mucho más vulnerables éstas) instintivos, impulsivos e irracionales por naturales. Por eso, la reacción contra esta revolución y la deriva utilitarista o hedonista de sus protagonistas sólo puede venir, paradójicamente, de la mano de actores fanáticos. Su mundo no es, como propuesta reaccionaria, el de la contención ni el del equilibrio, sino el de un fanatismo sublime y pasional al mismo tiempo.

La obra de Vélez, más allá de su significado general, es una obra concreta que no sólo responde a las peculiares circunstancias de la Guerra de la Independencia en España, sino de manera muy particular al notable hecho del surgimiento de un nuevo poder político manifestado en las Cortes y dotado de una nueva legitimidad en la recién aprobada Constitución de 1812. Su posición ante la misma no deja de ser sibilina: si, por una parte no puede dejar de considerarla como una norma nefasta, por otra no puede escapar, dentro de los márgenes más amplios pero siempre relativos del concepto de «tiranía», a una cierta valoración condescendiente o pragmática de la misma, desde el momento en que representa la respuesta legal y soberana a ese supuesto político que encarna, en este caso, Napoleón. Es, en definitiva, un elemento de seguridad frente a la falta de ley, la situación por antonomasia que define, en el contexto de las monarquías absolutas, la figura y la situación política de la 
«tiranía ${ }^{20}$. Es la misma situación incómoda o paradójica de un reaccionario que, utilizando las armas de la opinión pública, clama ante «los padres de la patria», creadores de la Constitución, que supriman de la misma la libertad de imprenta. Puede parecer, al final de todo el recorrido, una reducción de objetivos, pero en realidad es el punto neurálgico que pretende cerrar esos «ríos subterráneos» a través de los cuales ha discurrido el mal, ha penetrado la filosofía en España.

Javier Herrero ya calificó en su momento el Preservativo como uno de los ataques más violentos contra los liberales y como una de las obras de máxima influencia a lo largo del siglo. El mismo autor no duda tampoco a la hora de poner en evidencia el carácter acomodaticio de Vélez, capaz tanto de dirigirse «suavemente» a las Cortes como de acusar a la Constitución de un «republicanismo sin igual ${ }^{21}$. Lo que hemos pretendido en este trabajo es no sólo propiciar una nueva lectura del pensamiento reaccionario desde su emergencia a partir de la ruptura protagonizada por la experiencia revolucionaria, sino también de manera subsidiaria dejar planteado hasta qué punto, a partir de la situación creada entre 1808 y 1814, necesitamos repensar genealogías, tradiciones y sentidos comunes que han estado y siguen demasiado presentes en nuestra historiografía a la hora de definir las diversas opciones políticas enfrentadas.

20. Al respecto, una vez más, el trabajo ya citado de LóPEZ Alós, Javier, «Guerra de la Independencia...»

21. HERRERO, Javier, Los orígenes del pensamiento..., pp. 314-316. 